\title{
PEMBERIAN BUBUR TEMPE TERHADAP LAMANYA DIARE AKUT PADA BALITA DI PUSKESMAS PURUK CAHU
}

\author{
Happy Marthalena Simanungkalit ${ }^{\bowtie}$, Muliana \\ Jurusan Kebidanan Poltekkes Kemenkes Palangkaraya
}

\section{ARTICLE INFO \\ Article history}

Submitted : 2019-08-07

Revised : 2021-07-07

Accepted : 2021-07-26

\section{Keywords:}

Tempe porridge

Acute diarrhea

Toddler

\section{Kata Kunci:}

Bubur tempe

Diare akut

Balita

\begin{abstract}
Diarrhea is currently still the third leading cause of under-five mortality after pneumonia. Diarrhea is one of the diseases that causes death and illness in toddlers every year. One result of diarrhea is nutritional disorders due to reduced food intake, vomiting, hypoglycemia, dehydration which causes metabolic balance disorders because fluid intake is not balanced with expenditure through vomiting and diarrhea. The purpose of this study was to determine the difference in the duration of diarrhea when giving tempe porridge to toddlers at the Puruk Cahu Health Center. The design of this study is analytic research with this type of research is Quasi Experiment using the design of the Group Control Post Test Only Design. The population in this study were toddlers who had acute diarrhea in the working area of Puruk Cahu Health Center, Murung Raya Regency and the sample size was 38 people (19 people as the control group and 19 experimental groups). The statistical test used in this study was the Mann Whitney test. The results of statistical tests using the Mann Whitney test found that $p$ value $=0.002$ means the value of $\mathrm{p}$ value $<$ alpha (0.05), meaning that there is an effect of giving tempe porridge to the duration of diarrhea at Puruk Cahu Health Center. Diarrhea in the group that was not given tempeh porridge lasted longer than the group that was given tempeh porridge. The Conclusion is that there is a difference in the duration of acute diarrhea in the administration of tempe porridge for toddlers at the Puruk Cahu Health Center.

Diare saat ini masih menjadi penyebab utama ketiga kematian balita setelah pneumonia. Diare menjadi salah satu penyakit yang menyebabkan mortalitas dan morbiditas pada balita setiap tahun. Salah satu akibat dari diare adalah gangguan gizi akibat asupan makanan berkurang, muntah-muntah, hipoglikemia, dehidrasi yang menyebabkan gangguan keseimbangan metabolisme karena asupan cairan tidak seimbang dengan pengeluaran melalui muntah dan diare. Tujuan penelitian untuk mengetahui perbedaan lamanya diare pada pemberian bubur tempe pada balita di Puskesmas Puruk Cahu. Desain penelitian ini adalah penelitian analitik dengan jenis penelitian Quasi Eksperiment y ang menggunakan rancangan control grup post test only desain. Populasi pada penelitian ini adalah balita y ang mengalami diare akut di wilay ah kerja Puskesmas Puruk Cahu Kabupaten Murung Raya dan besar sampel penelitian ini sebanyak 38 orang (19 orang sebagai kelompok kontrol dan 19 orang kelompok eksperimen). Uji statistik yang digunakan pada penelitian ini adalah uji Mann Whitney. Hasil uji statistik dengan menggunakan uji Mann Whitney didapatkan nilai $\mathrm{p}$ value $=0.002$ berarti nilai $\mathrm{p}$ value < alpha (0.05), artiny a ada perbedaan pemberian bubur tempe terhadap lama diare di Puskesmas Puruk Cahu. Diare pada kelompok yang tidak diberikan bubur tempe lebih lama dari kelompok yang diberikan bubur tempe. Kesimpulannya ada perbedaan lama diare akut pada pemberian bubur tempe pada balita di Puskesmas Puruk Cahu.
\end{abstract}




\section{PENDAHULUAN}

Indonesia berada diurutan ketiga angka kesakitan dan kematian anak karena diare masih menjadi salah satu masalah kesehatan masyarakat. Diperkirakan 1,3 miliar serangan diare dan 3,2 juta kematian per tahun pada balita disebabkan oleh diare. Serangan diare rata-rata 3,3 kali setiap tahun pada setiap anak. Kematian pada anak berusia kurang dari dua tahun sekitar 80\% (Widoyono, 2011). Diare saat ini masih menjadi penyebab utama ketiga kematian balita setelah pneumonia. Dari tahun ke tahun menjadi salah satu penyakit yang menyebabkan mortalitas dan morbiditas pada balita (WHO, 2015). Indonesia adalah salah satu negara berkembang dengan masalah penyakit diare.

Pada tahun 2017 jumlah perkiraan kasus sebesar 3.382 dilihat dari $10 \%$ jumlah penduduk di Kabupaten Murung Raya dan yang ditangani tercatat 4.029 kasus pada anak diare atau mencapai $119,1 \%$ dari perkiraan kasus diare ditahun 2017 (Dinkes Murung Raya, 2017). Data Riset Kesehatan Dasar Provinsi Kalimantan Tengah tahun 2018 menyatakan bahwa prevalensi diare pada balita di Kabupaten Murung Raya adalah 8\%. Berdasarkan data di wilayah kerja Puskesmas Puruk Cahu pada tahun 2017 sebanyak $293(26,1)$ anak balita mengalami diare dan data pada tahun 2018 dari bulan Januari sampai Oktober tercatat sebanyak 409 $(22,1)$ anak balita yang mengalami diare.

Saat balita mengalami diare, anak akan kehilangan semangat, tidak ceria lagi dan selalu menangis karena mengeluh sakit pada perutnya. Selain itu gejala lain yang muncul adalah gangguan gizi akibat asupan makanan berkurang, muntah-muntah, hipoglikemia, dehidrasi yang menyebabkan gangguan keseimbangan metabolisme karena asupan cairan tidak seimbang dengan pengeluaran melalui muntah dan diare.

Untuk mengatasi masalah tersebut, pengobatan diare yang paling tepat pada anak balita adalah dengan menggantikan cairan yang hilang dan tidak menghentikan pemberian ASI maupun makanan lainnya. Makanan yang diberikan harus mudah dicerna dan cepat diserap zat-zat gizinya. Salah satu makanan yang telah diketahui mudah dicerna walaupun oleh orang yang menderita penyakit pada saluran pencernaannya adalah tempe.

Keunggulan tempe yaitu sumber vitamin B12, rendah lemak jenuh serta kolesterol, tinggi kandungan protein dan memberikan asam amino esensial. Tempe memiliki dampak sangat menguntungkan terhadap gizi dan kesehatan mulai dari proses fermentasi kedelai menjadi tempe, baik yang menyangkut perubahan fisik, biokimia maupun mikrobiologi. Mengubah kedelai menjadi tempe yang berasa lebih enak, lebih bergizi dan berfungsi sebagai makanan kesehatan merupakan manfaat Rhizopus sp.

Studi pemberian bubur tempe terhadap lamanya diare perlu dilakukan karena tempe mampu menyembuhkan diare terutama pada anak balita dan mudah dicerna dan diserap serta memilik zat anti-bakteri sehingga. Bahan makanan campuran yang menggunakan tempe sebagai komponennya terbukti bermanfaat bagi penanggulangan diare kronis pada anak. Berbagai penelitian menunjukan bahwa tempe mempunyai kemampuan dalam penanggulangan diare, hal ini disebabkan karena tempe mengandung asam amino dan serat yang tinggi selain unsur prebiotik dan probiotik.

Berdasarkan uraian di atas, maka peneliti tertarik melakukan penelitian ini yaitu meneliti perbedaan lama diare akut pada pemberian bubur tempe dan bubur predapada balita di Puskesmas Puruk Cahu

\section{METODE PENELITIAN}

\section{Jenis Penelitian}

Jenis penelitian yang digunakan adalah quasi eksperimen dengan studi control grup post test only desain (Sugiyono, 2016). Pada penelitian ini subjek yang digunakan adalah manusia. Peneliti sudah mendapat ijin dari komite etik penelitian Poltekkes Kemenkes Palangka Raya dan Badan Perencanaan dan Pembangunan Daerah, Penelitian dan Pengembangan Kota Palangkaraya.

\section{Lokasi dan Waktu Penelitian}

Penelitian dilaksanakan pada Bulan Januari Tahun 2019. Penelitian ini berlokasi di Puskesmas Puruk Cahu Kalimantan Tengah.

\section{Populasi dan Sampel}

Populasi penelitian adalah balita yang mengalami diare akut di wilayah kerja Puskesmas Puruk Cahu Kabupaten Murung Raya. Jumlah kelompok penelitian ada 2 yaitu kelompok kontrol tidak diberikan bubur tempe dan kelompok intervensi yang diberikan bubur tempe. Besar sampel diukur dengan menggunakan rumus Lemeshow dengan hasil besar sampel pada masing-masing kelompok sebanyak 19 orang.

\section{Pengumpulan Data}

Pengumpulan data pada penelitian ini menggunakan lembar observasi untuk pemantauan lama diare pada kedua kelompok sampai dengan diare berhenti sedangkan pengukuran status gizi dengan indikator grafik pertumbuhan anak meliputi usia, berat badan, dan tinggi badan serta mengisi format pendidikan ibu.

\section{Pembuatan Bubur Tempe}

Pembuatan bubur tempe dimulai dengan merebus beras dengan air hingga mendidih, masukkan tempe, aduk rata, masak hingga empuk dan blender hingga lembut kemudian siap dikonsumsi hingga diare sembuh.

\section{Uji Normalitas}

Hasilnya yaitu data tidak berdistribusi normal dan uji statistik yang digunakan adalah uji Mann Whitney.

\section{HASIL PENELITIAN}

Berdasarkan data pada tabel 1 dapat 
diketahui bahwa status gizi balita yang diberikan bubur tempe pada kategori normal yaitu 11 balita $(61,1 \%)$.
Pendidikan ibu yang diberikan bubur tempe terbanyak pada tingkat SMP yaitu sebanyak 10 ibu $(55,6 \%)$.

Tabel 1. Distribusi Frekuensi Status Gizi Balita dan Pendidikan Ibu di Puskesmas Puruk Cahu Tahun 2019

\begin{tabular}{|c|c|c|c|c|c|c|}
\hline \multirow{3}{*}{ Karakte ris tik } & \multicolumn{4}{|c|}{$\begin{array}{c}\text { Kelompok } \\
\end{array}$} & & \\
\hline & \multicolumn{2}{|c|}{$\begin{array}{c}\text { Diberikan } \\
\text { Bubur Tempe }\end{array}$} & \multicolumn{2}{|c|}{$\begin{array}{c}\text { Tidak Diberikan } \\
\text { Bubur Tempe }\end{array}$} & \multicolumn{2}{|c|}{ Total } \\
\hline & $\mathbf{n}$ & $\%$ & $\mathbf{n}$ & $\%$ & $\mathbf{n}$ & $\%$ \\
\hline \multicolumn{7}{|l|}{ Status gizi } \\
\hline Gemuk & 1 & 25,0 & 3 & 75,0 & 4 & 100 \\
\hline Normal & 11 & 61,1 & 7 & 38,9 & 18 & 100 \\
\hline Kurus & 3 & 42,9 & 4 & 57,1 & 7 & 100 \\
\hline Sangat kurus & 4 & 44,4 & 5 & 55,6 & 9 & 100 \\
\hline \multicolumn{7}{|l|}{ Pendidikan ibu } \\
\hline SD & 2 & 25,0 & 6 & 75,0 & 8 & 100 \\
\hline SMP & 10 & 55,6 & 8 & 44,4 & 18 & 100 \\
\hline SMA & 5 & 50,0 & 5 & 50,0 & 10 & 100 \\
\hline PT & 2 & 100,0 & 0 & 0,0 & 2 & 100 \\
\hline Total & 19 & 50,0 & 19 & 50,0 & 38 & 100 \\
\hline
\end{tabular}

Berdasarkan tabel 2 dapat diketahui bahwa lama diare pada kelompok yang diberikan bubur tempe lamanya 3 hari dan pada kelompok tidak diberikan bubur tempe lamanya diare 4 hari.

Dari tabel 3 dapat dilihat bahwa dengan jumlah sampel 19 responden untuk kelompok yang diberikan bubur tempe didapatkan nilai $\mathrm{p}$ $=0.016$ dan kelompok yang tidak diberikan bubur tempe didapatkan nilai $\mathrm{p}=0,001$ dengan ketentuan $\mathrm{p}<\alpha(0,05)$ jadi dapat disimpulkan bahwa data tidak berdistribusi normal.

Setelah diketahui bahwa hasil data penelitian tidak berdistribusi normal, maka dilakukan analisis antara dua kelompok (sampel) di dalam penelitian ini, uji statistik yang digunakan adalah uji Non parametrik dengan data tidak berpasangan yaitu uji Mann Whitney.

Tabel 2 Rata-Rata Lama Diare di Puskesmas Puruk Cahu Tahun 2019

\begin{tabular}{lccccc}
\hline \multicolumn{2}{c}{ Variabel } & Mean & SD & Min Rate & Max Rate \\
\hline $\begin{array}{l}\text { Lama diare pada kelompok yang } \\
\text { diberikan bubur tempe }\end{array}$ & 3,16 & 0,69 & 2 & 4 \\
\hline $\begin{array}{l}\text { Lama diare pada kelompok yang tidak } \\
\text { diberikan bubur tempe }\end{array}$ & 4,11 & 0,86 & 3 & 5 \\
\hline
\end{tabular}

Tabel 3. Hasil Uji Normalitas Lama Diare pada Kelompok yang Diberikan Bubur Tempe dan Yang Tidak Diberikan Bubur Tempe di Puskesmas Puruk Cahu Tahun 2019

\begin{tabular}{ccccc}
\hline & Pemberian Bubur & \multicolumn{3}{c}{ Shapiro-Wilk } \\
\cline { 3 - 5 } & Tempe & Statis tic & df & Sig. \\
\hline \multirow{2}{*}{ Lama diare } & Diberikan & .872 & 19 & .016 \\
& Tidak diberikan & .803 & 19 & .001 \\
\hline
\end{tabular}


Berdasarkan tabel 4 dapat dilihat bahwa nilai rata-rata lama diare pada kelompok yang diberikan bubur tempe adalah 3 hari sedangkan nilai rata-rata lama diare pada kelompok yang tidak diberikan bubur tempe adalah 4 hari dengan perbedaan nilai rata-rata 0,95 . Hasil uji statistik dengan menggunakan uji Mann Whitney didapatkan nilai $\mathrm{p}$ value $=0.002$ berarti nilai $\mathrm{p}$ value < alpha (0.05), artinya ada perbedaan lama diare akut pada pemberian bubur tempe di Puskesmas Puruk Cahu.

Tabel 4. Pemberian Bubur Tempe terhadap Lama Diare di Puskesmas Puruk Cahu Tahun 2019

\begin{tabular}{lcccc}
\hline \multicolumn{1}{c}{ Lama Diare } & Mean & Selisih Rata-Rata & SD & p value \\
\hline $\begin{array}{l}\text { Lama diare pada kelompok yang } \\
\text { diberikan bubur tempe }\end{array}$ & 3,16 & & 0,688 & \\
$\begin{array}{l}\text { Lama diare pada kelompok yang } \\
\text { tidak diberikan bubur tempe }\end{array}$ & 4,11 & 0,95 & 0,86 & 0,002 \\
\hline
\end{tabular}

\section{PEMBAHASAN}

Lama Diare pada Kelompok yang Dibe rikan dan Tidak Diberikan Bubur Tempe

Berdasarkan hasil penelitian lama diare pada kelompok yang diberikan bubur tempe lamanya 3 hari dengan SD 0,688 dan waktu tercepat adalah 2 hari dan waktu terlama 4 hari. Sedangkan rata-rata lama diare pada kelompok yang tidak diberikan bubur tempe lamanya 4 hari dengan SD 0,86 dan waktu tercepat adalah 3 hari dan waktu terlama 5 hari. Diare merupakan suatu penyakit yang di tandai dengan perubahan bentuk dan konsistensi tinja yang lembek sampai mencair dan bertambahnya frekuensi buang air besar yang dari biasa, yaitu 3 kali atau lebih dalam sehari yang mungkin dapat disertai dengan muntah dan tinja berdarah (WHO, 2015).

Menurut Hartiningrum (2010), Proses pembuatan makanan pada balita yang mengalami diare perlu memenuhi zat gizi (protein dan Kalori) yang mudah di serap oleh villi usus. Makanan bagi penderita diare harus disiapkan seperti bubur berbahan dasar tempe karena balita diare mengalami kehilangan cairan tubuh yang menyebabkan dehidrasi atau kehilangan cairan tubuh dan membuat tubuh tidak berfungsi dengan baik maka perawatan pertama dalam keluarga adalah memberikan cairan dan makan untuk mengganti cairan tubuh yang hilang.

Penggunaan Bahan Dasar Tempe sebagai Formula Makanan Tambahan bagi Balita mengalami Diare. Tempe memiliki efek anti mikroba, mengalami diare lebih pendek dibanding yang tidak makan berbahan dasar tempe dan mempercepat pertumbuhan anak yang menderita diare selain itu juga untuk pengobatan rehidrasi oral dan nutrisi awal di mana tempe sebagai bahan alternatif pengganti asam amino atau senyawa organik yang bergabung menjadi protein yang di perlukan oleh tubuh. Hal ini sesuai dengan penelitian Hartiningrum (2010) formula tempe dapat dipakai sebagai pengganti formula Preda pada anak dengan penyakit diare akut. Rata-rata lama penyakit diare pada pemberian formula Preda adalah 4,95 hari dan pemberian bubur tempe adalah 4,21 hari.

Selain itu penelitian Setiawati (2016) juga menyatakan bahwa diberikan bubur tempe, mayoritas frekuensi BAB pada anak yang mengalami diare menurun dari 5 - 10x/hari menjadi $1-4 \mathrm{x} /$ hari karena tempe mengandung komponen fungsional probiotik dan prebiotik, serat larut, asam lemak omega 3 polyunsaturated, konjugasi asam linoleat, antioksidan pada tanaman, vitamin dan mineral, beberapa protein, peptida dan asam amino seperti phospholipid.

Pada kelompok yang tidak diberikan bubur tempe terapi yang didapatkan adalah zink dan oralit karena menurut Manopo (2010), bahwa suplementasi zink pada diare akut efektif mengurangi keluaran tinja. Oralit adalah campuran garam elektrolit seperti natrium klorida $(\mathrm{NaCl})$, kalium klorida $(\mathrm{KCl})$, dan trisodium sitrat hidrat, serta glukosa anhidrat. Oralit diberikan untuk mengganti cairan dan elektrolit dalam tubuh yang terbuang saat diare, sehingga tidak akan terjadi dehidrasi. Akan tetapi dalam masa penyembuhan asupan makanan balita harus diperhatikan agar proses 
penyembuhan diare tidak akan berlangsung lama.

Kecukupan gizi pada penderita diare terutama pada anak bertujuan agar tetap kuat dan mencegah berkurangnya berat badan. Anak yang masih minum ASI harus lebih sering diberi ASI. Anak yang minum susu formula juga diberikan lebih sering dari biasanya. Makanan yang mudah dicerna dan diberikan sedikit lebih sedikit dan lebih sering pada anak usia 6 bulan atau lebih termasuk bayi yang telah mendapatkan makanan padat. Pemberian makanan tambahan diteruskan selama 2 minggu setelah diare berhenti untuk membantu pemulihan berat badan.

Mekanisme dasar penyebab diare adalah gangguan osmotik (makanan yang tidak dapat diserap akan menyebabkan tekanan osmotik dalam rongga usus meningkat sehingga terjadi pergeseran air dan elektrolit ke dalam rongga usus, isi rongga usus berlebihan sehingga timbul diare). Selain itu menimbulkan gangguan sekresi akibat toksin di dinding usus meningkat kemudian terjadi diare. Ganguan motiliasi usus yang mengakibatkan hiperperistaltik dan hipoperistaltik (Ariani, 2016). Oleh sebab itu proses pembuatan makanan perlu memenuhi zat gizi (protein dan Kalori) yang mudah di serap oleh villi usus makanan bagi penderita Diare.

Latar belakang pendidikan orang tua juga mempengaruhi lama kesembuhan penderita diare karena pendidikan yang tinggi seorang ibu lebih mengetahui cara memelihara kesehatan memilih dan mengolah bahan makanan sehingga bergizi untuk dikonsumsi. Sebaliknya seorang ibu yang memiliki pendidikan yang rendah menyebabkan kesadaran tentang pentingnya arti kesehatan balita juga rendah.

\section{Pemberian Bubur Tempe terhadap Lama Diare di Puskesmas Puruk Cahu}

Berdasarkan hasil penelitian bahwa perbedaan nilai rata-rata lama diare pada kelompok yang diberikan bubur tempe dan yang tidak adalah sebesar 0,95. Hasil uji statistik dengan menggunakan uji Mann Whitney didapatkan nilai $\mathrm{p}$ value $=0.002$ berarti nilai $\mathrm{p}$ value < alpha (0.05), artinya ada perbedaan rata-rata lama diare akut pada pemberian bubur tempe pada balita di Puskesmas Puruk Cahu. Pemberian bubur tempe terhadap pasien diare ini karena yang berbahan dasar tempe dapat mempersingkat durasi diare akut serta mempercepat pertambahan berat badan setelah menderita diare akut.

Tempe dipilih sebagai bahan dasar, karena tempe merupakan pangan tradisional yang mudah didapat, tempe mengandung komponen fungsional probiotik dan prebiotik, serat larut, asam lemak omega 3 polyunsaturated, konjugasi asam linoleat, antioksidan pada tanaman, vitamin dan mineral, beberapa protein, peptida dan asam amino seperti phospholipid.

Mikroorganisme banyak yang digunakan untuk memelihara produk pangan tradisional dengan cara fermentasi dan keberadaan makanan ini beragam angka mikroorganismenya yang dipertimbangkan sebagai prebiotik (Toole dan Cooney, 2008). Hartiningrum (2010) juga menyatakan bahwa formula tempe dapat dipakai sebagai pengganti formula Preda pada anak dengan penyakit diare akut.

Rata-rata lama penyakit diare pada pemberian formula Preda adalah 4,95 hari dan pemberian bubur tempe adalah 4,21 hari. Selain itu penelitian yang dilakukan oleh Darmita (2017) menyatakan bahwa pengaruh pemberian formula tempe berpengaruh terhadap penurunan frekuensi diare responden dikarenakan oleh kandungan tempe yaitu prebiotik dan makronutrien berupa protein dan lemak yang diabsorpsinya terganggu pada penderita diare, sedangkan prebiotik merupakan komponen nutrisi yang mampu memberikan efek pada aktivitas mikroorganisme dalam usus yaitu probiotik sebagai floral normal yang dapat berdampak pada penurunan peristaltik usus sehingga frekuensi $\mathrm{BAB}$ menurun. Hal lainnya adalah formula tempe mengandung protein yang lebih tinggi dibanding protein hewani sehingga dapat menambah daya tahan tubuh balita dengan diare.

Penelitian ini juga pernah dilakukan oleh Setiawati H (2015) yang bertujuan untuk mengetahui pengaruh pemberian bubur tempe terhadap frekuensi buang air besar pada anak diare di Rumah Sakit Surakarta yang menggunakan kuasi eksperimen. Sampel yang digunakan dalam penelitian ini terdiri dari 2 kelompok, yaitu 15 responden kelompok intervensi yang diberi bubur tempe dan 15 responden untuk kelompok kontrol yang diberi bubur preda dengan total responden 30 orang. 
Hasil penelitiannya menunjukkan frekuensi buang air besar sebelum diberikan bubur tempe antara 5-10 kali per hari yaitu sebanyak 7 anak $(46,67 \%)$, setelah diberikan bubur tempe frekuensi diare menjadi $1-4 x /$ hari yaitu sebesar 14 anak (93,33\%). Frekuensi buang air besar sebelum diberikan bubur preda antara 5 10x/hari yaitu sebesar 9 anak $(60 \%)$, setelah diberikan bubur preda masih terdapat 6 anak (40\%) yang frekuensi buang air besar antara $1-$ $4 \mathrm{x} /$ hari. Terdapat perbedaan rata-rata frekuensi buang air besar sebelum dan sesudah diberikan bubur tempe.

\section{Status Gizi Balita}

Berdasarkan hasil penelitian didapatkan bahwa status gizi balita pada kategori normal yaitu sebanyak 11 orang balita $(47,4 \%)$. Pada balita yang mengalami masalah gizi kurang serangan diare terjadi lebih sering. Diare yang semakin sering dan berat diderita akan semakin buruk keadaan status gizi balita,. Daya tahan tubuh yang kurang menyebabkan mukosa penderita malnutrisi sangat peka terhadap infeksi karena.

Status gizi pada anak sangat berpengaruh terhadap kejadian penyakit diare. Pada anak yang menderita kurang gizi dan gizi buruk yang mendapatkan asupan makan yang kurang mengakibatkan diare yang lebih lama dan sering. Risiko meninggal akibat diare persisten dan atau disentri sangat meningkat bila anak sudah mengalami kurang gizi. Beratnya penyakit, lamanya dan risiko kematian karena diare meningkat pada anakanak dengan kurang gizi, apalagi pada yang menderita gizi buruk (Palupi, 2009).

\section{Pendidikan Ibu}

Berdasarkan hasil penelitian didapatkan Berdasarkan hasil penelitian didapatkan bahwa mayoritas pendidikan ibu pada tingkat SMP yaitu sebanyak 10 orang ibu $(55,6 \%)$. Pendidikan orang tua adalah salah satu faktor yang mempengaruhi kejadian diare pada balita. Pengetahuan yang rendah untuk pencegahan diare cenderung disebabkan orang tua atau ibu balita yang berpendidikan rendah. Informasi kesehatan dan cara-cara pencegahan penyakit yang dialami khususnya penyakit diare dan dehidrasi saat diare akan lebih mudah diterima dengan semakin tingginya pendidikan ibu serta semakin banyak informasi kesehatan yang diterima, akan semakin banyak juga pengetahuan yang diperoleh, termasuk pengetahuan kesehatan dalam penanganan diare (Hartati dan Nurazila, 2018).

\section{KESIMPULAN DAN SARAN}

Rata-rata lama diare pada kelompok yang diberikan bubur tempe lebih cepat 2 hari dari kelompok yang tidak diberikan bubur tempe. Ada perbedaan lama diare terhadap pemberian bubur tempe di Puskesmas Puruk Cahu. Hal ini juga dapat dipengaruhi oleh status gizi balita dan pendidikan ibu balita.

Bagi masyarakat yang memiliki balita dengan diare dapat memberikan bubur berbahan dasar tempe yang ekonomis dan mudah didapat serta mampu mempercepat kesembuhan diare dan memberikan asupan gizi yang dibutuhkan saat mengalami diare. Bagi peneliti selanjutnya dapat melakukan penelitian terkait pemberian bubur tempe dengan menggunakan variabel dependen lain dan sampel yang lebih besar.

\section{DAFTAR PUSTAKA}

Ariani, P. (2016). Diare pencegahan dan pengobatan. Yogyakarta: Nuha Medika.

Dinas Kesehatan Provinsi Kalteng. (2018). Profil kesehatan provinsi kalteng.

Dinkes Kesehatan Kabupaten Murung Raya. (2017). Profil kesehatan kabupaten Murung Raya.

Ditjen P2PL. (2009). Diare. www. infopenyakit.org (online).

Hartiningrum, S.Y. (2010). Pengaruh pemberian Formula Freda dan Tempe pada Balita Usia 6 - 24 Bulan di RSU. RA Kartini Kabupaten Jepara. Skripsi Magister Program Studi Gizi. Semarang: Universitas Diponegoro.

Kementerian Kesehatan Direktorat Jenderal Bina Gizi dan Kesehatan Ibu dan Anak. (2012). Tentang Standar Antropometri Penilaian status Gizi Pada Anak.

Setiawati, H. (2016). Pengaruh Pemberian Diet Bubur Tempe terhadap Frekuensi BAB Pada diare Di Ruang Mina rumahsakit PKU Muhammadiyah Surakarta. Universitas Muhammadiyah Surakarta.

Sugiyono. (2016). Metode Penelitian Kuantitatif Dan Kualitatif. Bandung: Alfabeta.

Toole, P.W.O dan Cooney. J.C. (2008). Probiotics Bacteria Influence The Composition and Function of The 
Intestinal Microbiota. Review Article. Ireland.

Widoyono. (2011). Penyakit Tropis Epidemiologi, Penularan, Pencegahan \& Pemberantasannya. Jakarta: Erlangga.
World Health Organization. (2015). World report on ageing and health. World Health Organization. 